\title{
Assessment of Sorptive Properties of Selected Tropical Wood Species
}

\section{Određivanje sorpcijskih svojstava nekih tropskih vrsta drva}

\author{
Original scientific paper • Izvorni znanstveni rad \\ Received-prispjelo: 31. 7. 2017. \\ Accepted-prihvaćeno: 21. 2. 2018. \\ UDK: $630 * 812.22$ \\ doi:10.5552/drind.2018.1733
}

\begin{abstract}
This study is primarily focused on broadening the knowledge on sorptive properties of tropical wood species. The main objective of this research was to determine the equilibrium moisture content (EMC) of 17 selected tropical wood species vital to the flooring industry in Europe. For comparison, selected European wood species - European beech, European oak and Scots pine, were also tested. Differences in the EMC between wood from temperate and tropical zones were established, resulting in the necessity of revising the knowledge, especially in wooden floor production. The results show that the EMC of tropical wood species is generally lower than that of temperate region wood species. African padouk, Teak, Afzelia and Ipe showed the lowest values of moisture content. Furthermore these wood species showed the lowest values of fibre saturation point $(17.7 \%, 22.5 \%, 19.7 \%$ and $18.7 \%$, respectively). Secondly, it was established that the basic density has significant influence on sorption properties of tested wood species. Further to the above, it was concluded that - the higher wood basic density, the larger are the changes of dimensions. Consequently, based on the results obtained, the possibility of supplementing the recommendations in industry standards regarding wooden floors should be considered.
\end{abstract}

Keywords: equilibrium moisture content, tropical wood, sorption, flooring

SAŽETAK • Studija je ponajprije usredotočena na širenje znanja o sorpcijskim svojstvima tropskih vrsta drva. Glavni je cilj istraživanja bio utvrditi ravnotežni sadržaj vode (EMC) za 17 odabranih tropskih vrsta drva važnih za industriju podnih obloga u Europi. Radi usporedbe, ispitane su i ove europske vrste drva: bukva, hrast i obični bor. Utvrđene su razlike u vrijednostima EMC-a između vrsta drva iz umjerenih $i$ vrsta drva iz tropskih zona, što upućuje na potrebu revizije znanja, posebno u proizvodnji drvenih podnih obloga. Rezultati su pokazali da je vrijednost EMC-a tropskih vrsta drva općenito niža nego za vrste iz umjerenog područja. Najniže vrijednosti ravnotežnog sadržaja vode zabilježene su za drvo afričkog padouka, tika, afzelije i ipea. Nadalje, za te su vrste drva dobivene i najniže vrijednosti točke zasićenja vlakanaca $(17,7 ; 22,5 ; 19,7 ; 18,7 \%)$. Osim toga, utvrđeno je da nominalna gustoća drva ima značajan utjecaj na sorpcijska svojstva ispitivanih vrsta drva. Iz toga se može zaključiti da će posljedica veće nominalne gustoće drva biti i veće promjene dimenzija drva. Sukladno tome, treba razmotriti donošenje dopune preporuka u industrijskim standardima koji se odnose na drvene podne obloge.

Ključne riječi: ravnotežni sadržaj vode, tropske vrste drva, sorpcija, podne obloge

\footnotetext{
${ }^{1}$ Author is Assistant Professor at Warsaw University of Life Sciences - SGGW, Department of Wood Sciences and Wood Protection, Faculty of Wood Technology, Warsaw, Poland.

${ }^{1}$ Autorica je docentica Sveučilišta bioloških znanosti u Varšavi - SGGW, Fakultet drvne tehnologije, Odjel za znanost o drvu i zaštitu drva, Varšava, Poljska.
} 


\section{INTRODUCTION}

\section{UVOD}

The sorption isotherms are essential properties in the analysis and design of various biological material processes such as preservation, drying, storing, packaging, mixing and using in production floors, furniture and others (Salin, 2011). As a hygroscopic material, wood shows significant changes in moisture content depending on climatic conditions. Due to relative humidity changes of the air, the phenomena of swelling and shrinkage of wood causes dimensional changes in finished products. In spite of a large number of wood species, data from the sorption isotherm of fir wood is usually used for the evaluation of the sorption behavior of domestic wood species, (Popper et al., 2007).

The mechanism and rate of wood humidity change is directly dependent on the parameters characterizing the indoors climate, while climate interiors through all the year is molded by exterior conditions and heating system. The air temperature in heated rooms during winter time is much higher than outside temperature. Coming into buildings, the cold atmospheric air (with high relative humidity) causes gradual drying of the indoor air. Relative humidity of the indoor air in summer can be $70 \%$ and decreases at the end of winter to $40 \%$ or even lower. The lower the outside temperature, the greater is the drying effect of external air. The result of these changes is wood moisture content change. In buildings with central heating system, wood moisture content is at the level of approx. $13 \%$ at the end of summer and decreases to even $5 \%$ at the end of winter (Krzysik and Sobczak, 1960).

Many studies were conducted on wood from moderate climate zones (Central Europe, North America). Due to a large number of wood species, the knowledge in this field of expertise is still incomplete. Furthermore, the equilibrium moisture content (EMC) of many wood species varies within a relatively broad range (Popper et al. 2007, 2009; Adampoulos and Voulgarridis, 2012). Few studies on tropical woods indicate the occurrence of variations in the sorption properties between species, which was corelated to the presence of high extractives content (Wangaard and Granados, 1967; Hernandez, 2007; Popper et al., 2006, 2007; Jankowska and Kozakiewicz, 2016; Jankowska et al., 2017). A comprehensive presentation of the sorption behavior of around 100 wood species was given by Keylwerth (1969). This list of wood species includes a lot of species from moderate climate and tropical zones. However, most of them are not present on European market of wood products, while wood species used nowadays were not included by this author. The studies conducted later give some information that should be included. Deliiski (2011) presents wood sorption isotherms, but no specific data is given on each species. Jannot et al. (2006) determined desorption isotherms and estimated specific areas of four selected tropical wood species from Africa (Doussié, Moabi, Ebony, Obeche and Iroko) at different temperatures. Sorption behavior of four tropical woods from
Africa was investigated by Sigmo-Tagne et al. (2016). Popper et al. (2006, 2007) also carried out research about sorptive properties of tropical wood species. Most of the presented data does not find use in practical application of tropical wood species in Europe, because wood species tested in the mentioned research are not currently present on European market. The knowledge in this area is lacking. This has also been confirmed by a number of studies made for the Association of Engineers and Technicians of Forestry and Wood Industry (Poland) dealing with products made of tropical wood such as floor, elevation, furniture, etc. This problem was emphasized in trade press (eg. Wróżek and Romanovski, 2014).

Determining properties of commercial wood available on the European market is an important issue and results of research should be taken into account during the design stage. The knowledge in this area will help to avoid many problems in the use of wooden products such as floor. The main aim of this work was to determine and compare the EMC of wood species used in floors production in Europe as well as to improve the knowledge of the tropical wood sorptive properties. The sorption tests were combined with the measurements of physical properties providing the value of fiber saturation point (FSP) of wood species selected for the tests. This group includes tropical woods from Africa, South American and tropical parts of Asia.

\section{MATERIALS AND METHODS}

2. MATERIJALI I METODE

\subsection{Materials}

2.1. Materijali

The wood species used in this study are presented in Tab. 1. The selected species are widely used in flooring production in Europe. Selection was made in order to have a representative sample of hardwoods, with a wide range of density and different anatomical structures. According to Popper et al. (2006, 2007), Jankowska et al. (2017), the selected species represent different types and amounts of extraneous substances. European wood species were used as a reference. All test materials were heartwood because it is commercially more important than sapwood. Wood from each species was acquired from DLH Poland, Warsaw, Poland. Material was identified in the laboratory using both macroscopic and microscopic techniques.

The samples of each wood species were collected from one log. Thus, differences in tested properties caused by differences in wood anatomy were avoided. Each part was quarter-sawn to produce planks of $4 \mathrm{~cm}$ thickness. Prior to samples preparation, wood was conditioned to air-dry in a room with relative humidity of 40-60\% and temperature of approx. $21^{\circ} \mathrm{C}$. The defectfree planks were sawn and sized to samples for moisture sorption and dimensional stability tests. For each wood species, 10 samples were used. Dimensions of the samples were $30 \mathrm{~mm}($ tangential $) \times 30 \mathrm{~mm}$ (radial) $\times 5 \mathrm{~mm}$ (longitudinal). 
Table 1 Wood species used in this study

Tablica 1. Istraživane vrste drva

\begin{tabular}{|l|l|l|l|}
\hline Wood name* / Naziv vrste & Latin name / Latinski naziv & Family / Porodica & Origin/ Podrijetlo \\
\hline African mahogany / afrički mahagonij & Khaya sp. & Meliaceae & Ghana \\
\hline African padouk / afrički padouk & Pterocarpus sp. & Fabaceae & Gabon \\
\hline Courbaril / jatoba & Hymenaea sp. & Caesalpiniaceae & Brazil \\
\hline Cumaru / kumaru & Dipteryx sp. & Fabaceae & Brazil \\
\hline Doussié / afzelija & Afzelia sp. & Caesaliniaceae & Ghana \\
\hline European beech / bukva & Fagus sp. & Fagaceae & Poland \\
\hline European oak / hrast & Quercus sp. & Fagaceae & Poland \\
\hline Ipe / ipe & Tabebuia sp. & Bignoniaceae & Brazil \\
\hline Iroko / iroko & Milicia sp. & Moraceae & Cameroon \\
\hline Light red meranti / svjetlocrveni meranti & Shorea sp. & Dipterocarpaceae & Indonesia \\
\hline Massaranduba / balata & Manilkara sp. & Sapotaceae & Brazil \\
\hline Merbau / merbau & Intsia sp. & Caesalpiniaceae & Burma \\
\hline Opepe / opepe & Nauclea sp. & Rubiaceae & Ghana \\
\hline Owangkol / bubinga & Guibourtia sp. & Caesalpiniaceae & Ghana \\
\hline Sapele / sapele & Entandophragma sp. & Meliaceae & Ghana \\
\hline Scots pine / obični bor & Pinus sp. & Pinaceae & Poland \\
\hline Sucupira / brazilski lješnjak & Bowdichia sp. & Fabaceae & Brazil \\
\hline Tatajuba / tatajuba & Bagassa sp. & Moraceae & Brazil \\
\hline Tauari / brazilski hrast & Couratari sp. & Lecythidaceae & Brazil \\
\hline Teak / tik & Tectona sp. & Verbenaceae & Burma \\
\hline Wenge / wenge & Millettia sp. & Fabaceae & Gabon \\
\hline
\end{tabular}

* Wood names are given according to PN-EN 13556:2005. / Nazivi vrsta drva u skladu su s normom PN-EN 13556:2005.

\subsection{Methods}

\subsection{Metode}

The specimens were exposed to moisture sorption test in adsorption and desorption. Five different relative humidities ranging from 9 to $97 \%$ were used followed by immersion treatment in water. As soon as each point of sorption was completed, the mass of specimens was measured to the nearest $0.001 \mathrm{~g}$ and their dimensions were taken to the nearest $0.01 \mathrm{~mm}$. The conditioning of specimens to appropriate moisture content was performed with the use of sealed enclosures in which prescribed saturated salt solutions were placed at the temperature close to $20^{\circ} \mathrm{C}$. The relative humidity was monitored and recorded using a hygrom-

Table 2 Relative humidity of air at constant temperature $20 \pm 2{ }^{\circ} \mathrm{C}$ obtained in sealed enclosures with the use of saturated salt solutions

Tablica 2. Relativna vlažnost zraka pri stalnoj temperaturi od $20 \pm 2{ }^{\circ} \mathrm{C}$ izmjerena u zatvorenim kutijama uz uporabu otopina zasićenih soli

\begin{tabular}{|l|c|}
\hline \multicolumn{1}{|c|}{$\begin{array}{c}\text { Saturated salt solution } \\
\text { Zasićena otopina soli }\end{array}$} & $\begin{array}{c}\text { Relative humidity in (\%) } \\
\text { at } \mathbf{2 0} \pm \mathbf{2}{ }^{\circ} \mathbf{C} \\
\text { Relativna vlažnost zraka } \\
\text { (\%) pri } 20 \pm 2{ }^{\circ} \mathrm{C}\end{array}$ \\
\hline $\begin{array}{l}\text { Potassium hydroxide } \mathrm{KOH} \\
\text { kalijev hidroksid, } \mathrm{KOH}\end{array}$ & 9 \\
\hline $\begin{array}{l}\text { Magnesium chloride } \mathrm{MgCl}_{2} \\
\text { magnezijev klorid, } \mathrm{MgCl}\end{array}$ & 30 \\
\hline $\begin{array}{l}\text { Sodium bromide } \mathrm{NaBr} \\
\text { natrijev bromid, } \mathrm{NaBr}\end{array}$ & 55 \\
\hline $\begin{array}{l}\text { Sodium chloride } \mathrm{NaCl} \\
\text { natrijev klorid, } \mathrm{NaCl}\end{array}$ & 76 \\
\hline $\begin{array}{l}\text { Potassium sulfate } \mathrm{K}_{2} \mathrm{SO}_{4} \\
\text { kalijev sulfat, } \mathrm{K}_{2} \mathrm{SO}_{4}\end{array}$ & 97 \\
\hline
\end{tabular}

eter. The salt solutions used to create various relative humidity of air at $20 \pm 2{ }^{\circ} \mathrm{C}$ are listed in Table 2 . A criterion for equilibrium was established as three successive identical mass readings at 24-hour intervals.

The equilibrium moisture content (EMC) of samples was determined according to PN-D-04100:1977 and ISO 3130:1975. The wood basic density of samples was determined according to PN-D-04101:1977 and ISO 3131:1975. The volumetric shrinkage of wood was also determined according to PN-D-04111:1982 and ISO 4858:1982. Moreover, the fiber saturation point (FPS) was estimated by the interpolation method between volumetric shrinkage and moisture content according to Jankowska and Kozakiewicz (2016).

Statistical analysis of the test results was carried out using Statistica v. 10 software (StatSoft, Inc.). Data were analyzed and provided as the mean \pm standard deviation and minimum and maximum values. Regression analysis was used to evaluate relationships between the measured properties. The effects of wood basic density on equilibrium moisture content and dimensional stability were determined. Moreover, t-test was used to verify the significance of differences among the average values.

\section{RESULTS AND DISCUSSION 3. REZULTATI I RASPRAVA}

The average values of the measured EMC for adsorption and desorption at $20^{\circ} \mathrm{C}$ are shown in Table 3 . For each tested wood species, the EMC at different relative humidity of air is individual. The highest differences in moisture content between tested wood species can be seen at higher relative humidity (approx. 97 $\%$ ). The results show that the EMC of tropical wood 


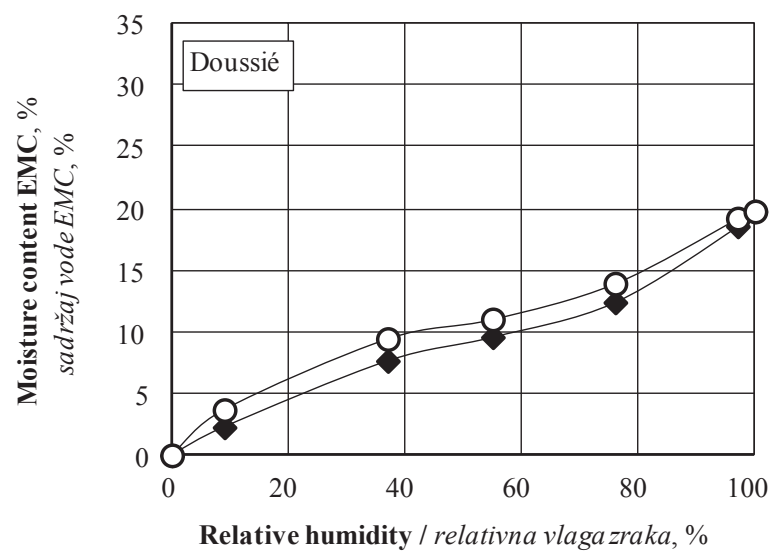

Figure 1 Adsorption and desorption isotherm of Doussié Slika 1. Krivulje adsorpcije i desorpcije za drvo afzelije

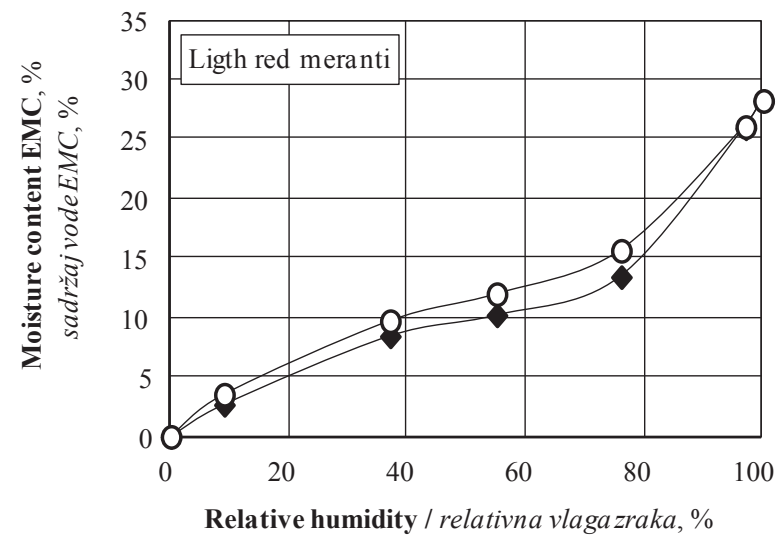

Figure 3 Adsorption and desorption isotherm of Light red meranti

Slika 3. Krivulje adsorpcije i desorpcije za drvo svjetlocrvenog merantija

species is generally low (Table 3 ). The highest values of moisture content were observed for European wood species, especially in case of European beech. The lowest values of moisture content were observed for African padouk, Teak, Doussié and Ipe. Among tropical wood species, Light red meranti, Merbau, Massaranduba, Sapele and Tauari showed the highest values of moisture content at different air conditions. This was probably caused by the relatively low content of nonpolar extractives of these species (Wanshura et al., 2014; Jankowska et al., 2017). According to t-test results, the difference between equilibrium moisture content of European oak, European beech and Scots pine are not significant. The European wood samples displayed significantly (the significance value was less than 0.05 ) higher value of equilibrium moisture content than tropical wood samples when air humidity was $55 \%$ and above. In case of low air humidity, the differences were not observed. As it is known from former studies (Choong and Achmadi, 1991; Popper et al., 2007; Adampoulos and Voulgarridis, 2012; Jankowska et al., 2017), the difference between equilibrium moisture content of European wood and tropical wood is caused by the amount of extractives in wood structure, which can be hydrophobic.

Fig. 1-3 show the adsorption and desorption isotherms for selected species used in this study. To avoid

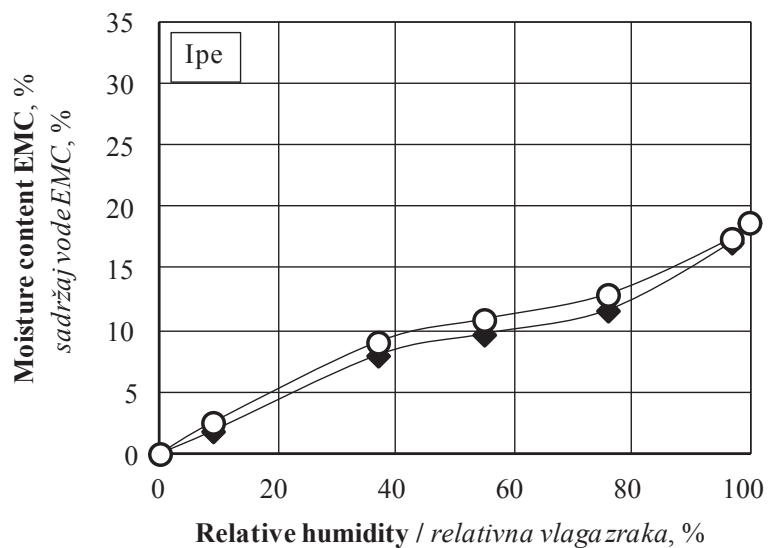

Figure 2 Adsorption and desorption isotherm of Ipe Slika 2. Krivulje adsorpcije i desorpcije za drvo ipea

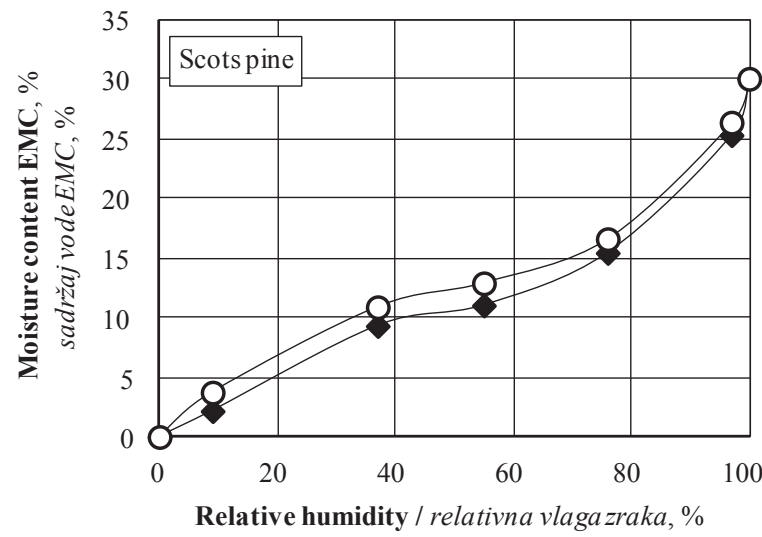

Figure 4 Adsorption and desorption isotherm of Scots pine Slika 4. Krivulje adsorpcije i desorpcije za drvo običnog bora

double presenting of the results, only isotherms for a few wood species are presented as examples.

This study fills an important gap concerning moisture content of tropical wood species used in Europe. Due to a lack of information on sorptive properties of tropical species, according to the European standards on wooden floors - PN-EN 13227:2004, PNEN 13629:2012, PN-EN 13226:2009, the proper value of wood moisture content should range from 7 to $11 \%$ when air temperature is about $20 \pm 3{ }^{\circ} \mathrm{C}$ and air humidity $50 \pm 5 \%$. Regarding the results obtained during this study, it can be said that such a wide range of recommended wood moisture content causes problems in choosing the proper value, especially due to the fact that tropical wood species are generally characterized by lower moisture content in comparison to European wood species. According to the results obtained, the EMC of wood in the air temperature close to $20^{\circ} \mathrm{C}$ and relative humidity of $55 \%$ can range from 7.50 to 12.96 $\%$ (Table 3 ). With so many differences in the sorption properties of wood, (especially in case of tropical wood species), the possibility of supplementing the recommendations in industry standards regarding wooden floors should be considered.

The results of density and shrinkage of the tested wood species are summarized in Table 4. High variation was observed in swelling properties among the tested 
Table 3 Change in equilibrium moisture content in adsorption and desorption of selected tropical and European wood species depending on relative humidity

Tablica 3. Promjena ravnotežnog sadržaja vode u adsorpciji i desorpciji istraživanih tropskih i europskih vrsta drva ovisno o relativnoj vlazi zraka

\begin{tabular}{|l|c|c|c|c|c|}
\hline \multirow{2}{*}{$\begin{array}{c}\text { Wood name } \\
\text { Vrsta drva }\end{array}$} & \multicolumn{5}{c|}{$\begin{array}{c}\text { Equilibrium moisture content at relative humidity } \\
\text { Ravnotežni sadržaj vode pri relativnoj vlazi zraka }\end{array}$} \\
\cline { 2 - 6 } & 9 & 37 & 55 & \multicolumn{3}{c|}{76} \\
\cline { 2 - 5 } & \multicolumn{4}{c|}{$\%$} \\
\hline African mahogany / afrički mahagonij & $2.85 / 4.25$ & $7.15 / 9.14$ & $9.14 / 12.0$ & $12.39 / 13.93$ & $24.18 / 25.01$ \\
\hline African padouk / afrički padouk & $1.46 / 2.63$ & $4.79 / 5.55$ & $7.50 / 8.54$ & $10.32 / 11.15$ & $14.47 / 15.81$ \\
\hline Courbaril / jatoba & $2.06 / 2.99$ & $8.60 / 9.45$ & $9.84 / 11.25$ & $11.87 / 12.98$ & $19.99 / 20.26$ \\
\hline Cumaru / kumaru & $1.86 / 3.07$ & $7.55 / 8.45$ & $9.45 / 10.67$ & $12.30 / 13.91$ & $21.20 / 21.47$ \\
\hline Doussié / afzelija & $2.26 / 3.66$ & $7.62 / 9.40$ & $9.54 / 10.98$ & $12.35 / 13.8$ & $18.49 / 19.13$ \\
\hline European beech / bukva & $2.15 / 2.91$ & $8.67 / 10.00$ & $11.86 / 12.96$ & $12.83 / 15.13$ & $30.81 / 31.05$ \\
\hline European oak / hrast & $2.19 / 3.45$ & $8.64 / 10.20$ & $11.78 / 12.80$ & $13.64 / 15.61$ & $26.15 / 27.01$ \\
\hline Ipe / ipe & $1.83 / 2.52$ & $7.95 / 9.01$ & $9.65 / 10.84$ & $11.59 / 12.87$ & $17.09 / 17.40$ \\
\hline Iroko / iroko & $2.17 / 3.25$ & $6.15 / 7.25$ & $8.29 / 9.50$ & $10.55 / 12.91$ & $18.61 / 19.95$ \\
\hline Light red meranti / svjetlocrveni meranti & $2.69 / 3.54$ & $8.44 / 9.71$ & $10.20 / 11.98$ & $13.41 / 15.62$ & $25.90 / 26.01$ \\
\hline Massaranduba / balata & $2.01 / 3.51$ & $6.87 / 8.01$ & $8.40 / 11.15$ & $12.71 / 16.21$ & $25.50 / 27.90$ \\
\hline Merbau / merbau & $2.52 / 3.47$ & $9.10 / 10.62$ & $11.84 / 12.20$ & $13.47 / 14.52$ & $21.78 / 21.90$ \\
\hline Opepe / opepe & $2.09 / 3.01$ & $8.60 / 9.15$ & $10.45 / 11.23$ & $12.80 / 14.64$ & $20.73 / 21.47$ \\
\hline Owangkol / bubinga & $2.09 / 3.39$ & $8.58 / 9.78$ & $10.30 / 11.51$ & $12.00 / 13.33$ & $23.00 / 23.50$ \\
\hline Sapele / sapele & $2.90 / 4.38$ & $9.16 / 10.10$ & $11.39 / 12.49$ & $13.14 / 15.50$ & $24.77 / 24.98$ \\
\hline Scots pine / obični bor & $2.16 / 3.72$ & $9.29 / 10.87$ & $11.01 / 12.87$ & $15.41 / 16.57$ & $25.27 / 26.33$ \\
\hline Sucupira / brazilski lješnjak & $1.81 / 2.92$ & $7.47 / 8.59$ & $8.87 / 10.68$ & $11.92 / 13.32$ & $24.20 / 24.33$ \\
\hline Tatajuba / tatajuba & $2.10 / 3.20$ & $7.87 / 8.54$ & $9.95 / 11.10$ & $11.71 / 12.81$ & $19.03 / 19.38$ \\
\hline Tauari / brazilski hrast & $2.03 / 3.22$ & $8.10 / 9.32$ & $9.87 / 11.24$ & $12.44 / 14.08$ & $23.61 / 24.00$ \\
\hline Teak / tik & $1.83 / 2.97$ & $7.77 / 8.81$ & $9.15 / 10.34$ & $11.23 / 13.02$ & $20.17 / 20.19$ \\
\hline Wenge / wenge & $1.63 / 2.80$ & $7.15 / 8.49$ & $8.97 / 11.20$ & $11.70 / 12.88$ & $19.16 / 20.36$ \\
\hline
\end{tabular}

wood species. The results of regression analysis (Fig. 5) showed that the wood density had significant influence on the volumetric shrinkage coefficient $(\beta \mathrm{v} / \mathrm{FSP})$ of the tested wood species ( $R^{2}$ value of 0.57$)$. Regression anal- ysis indicated a statistically significant relationship at the $95 \%$ confidence level (the significance value of the linear regression analysis was less than 0.05 ). When Teak and Merbau were not included in this analysis, the

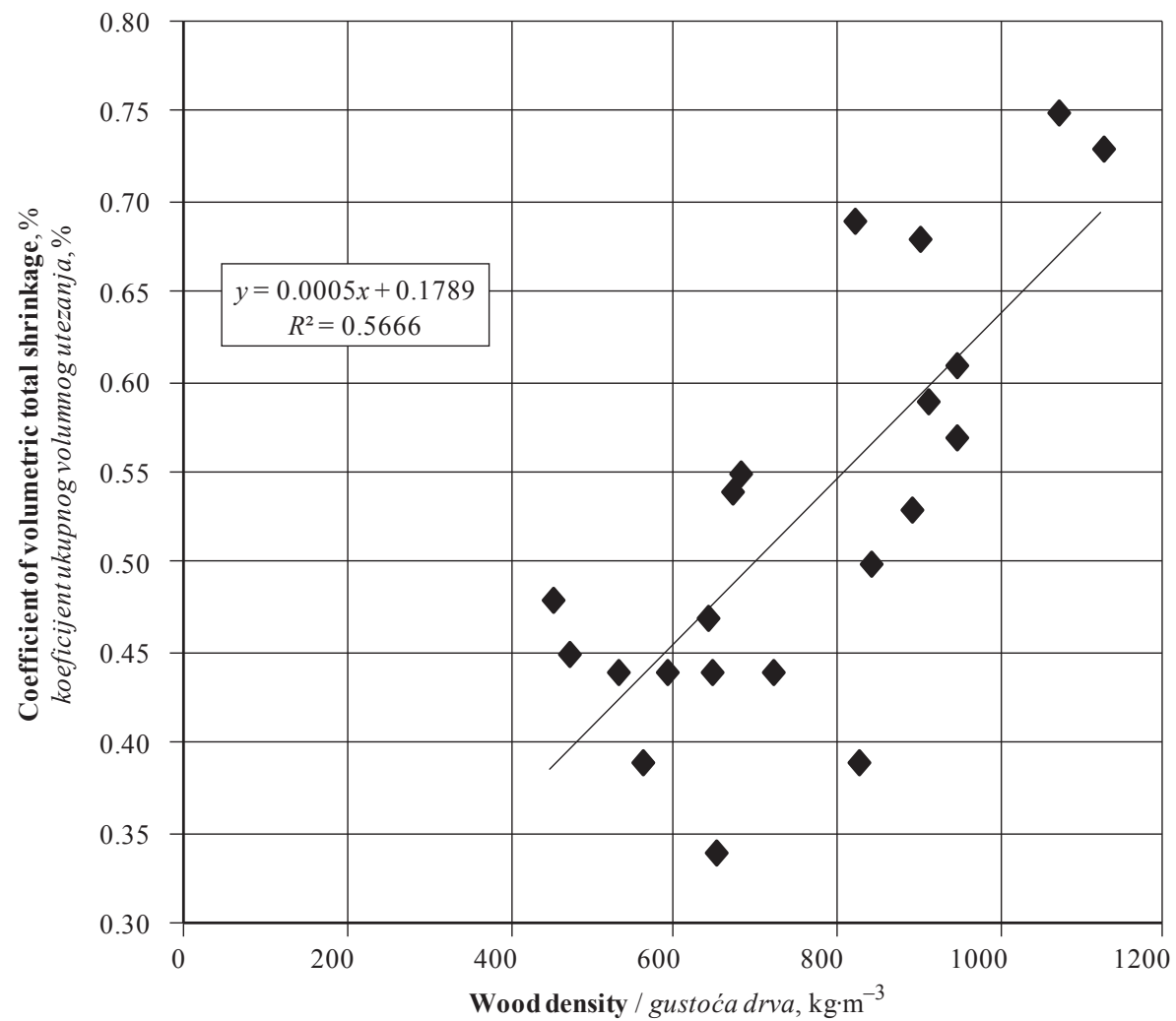

Figure 5 The influence of basic density of tested tropical and European wood species on the coefficient of volumetric total shrinkage Slika 5. Utjecaj nominalne gustoće istraživanih tropskih i europskih vrsta drva na koeficijent ukupnoga volumnog utezanja 
relationship between the basic density and coefficient of volumetric total shrinkage of wood was higher $\left(R^{2}\right.$ value of 0.70$)$. This can be caused by the chemical composition of these wood species. According to former studies (Mantanis et al. 1994; Adamopoulos and Voulgaridis 2012; Jankowska et al. 2017), it could be predicted that Merbau wood will show relatively low moisture content, because of high content of water soluble extractives. This is due to the bulking effect of extractives, which are partly deposited on the cell walls. The low moisture content values observed in case of Teak wood is an effect of higher content of chloroform-ethanol extractives and relatively low contents of hot water extractives (Jankowska et al., 2017).

Analysis of data given in Table 4 revealed that the values of the volumetric shrinkage of some wood species (African mahagony, Cumaru, Iroko, Massaranduba, Sucupira) are larger than the sum of radial and tangential shrinkage. This phenomenon can be explained by the fact that the above said wood species are characterized by irregular fiber arrangement. Consequently, the main anatomical directions are distorted and as a result dimension changes can be higher than when wood exhibits a simple fiber arrangement (as in case of European beech). Regarding the results presented in Table 4, it can be concluded that fiber saturation point (FSP) of tested wood species varied within a broad range from $17.7 \%$ (in case of African padouk) to $31.2 \%$ (in case of European beech). FSP was nega- tively correlated with wood density, but the correlation $\left(R^{2}=0.39\right)$ was rather low. According to previous studies (Jankowska et al., 2017), the relationship between wood density and its sorptive properties can be strongly affected by the high variability of extractives content. The observed volumetric shrinkage varied from $7.65 \%$ to $21.0 \%$. The lowest value was observed in Teak wood, and the highest in case of Massaranduba wood. The relationship between volumetric shrinkage (sum of radial and tangential shrinkage) and specific density has been already confirmed be several authors (Choong and Achmadi, 1991; Hernández, 2007). Moreover, wood density had an influence on the fiber saturation point during the testing of nine tropical hardwoods from Peru and sugar maple wood from Quebec (Hernández, 2006). According to results of Jankowska et al. (2017), the relationship between wood basic density and its sorptive properties is strongly affected by high extractives content and it is clear only when material with high extractives content is analyzed. Despite the reported relationship between volumetric shrinkage and wood density, no significant correlation was found in this study. It has been already confirmed by Hernández (2007) that wood density has a positive effect on total volumetric shrinkage However, the analysis of total volumetric shrinkage and wood density did not give a clear confirmation of significant relationship. The relationship was not significant $(P<0.1)$, and the correlation $\left(R^{2}=0.24\right)$ was also rather low, indicating

Table 4 Wood basic density, dimensional changes and fiber saturation point of tested tropical and European wood species Tablica 4. Nominalna gustoća drva, dimenzijske promjene i točka zasićenja vlakanaca istraživanih tropskih i europskih vrsta drva

\begin{tabular}{|c|c|c|c|c|c|}
\hline \multirow{3}{*}{$\begin{array}{l}\text { Wood name } \\
\text { Vrsta drva }\end{array}$} & \multirow{2}{*}{$\begin{array}{l}\text { Wood basic density } \\
\text { Nominalna gustoća } \\
\text { drva }\end{array}$} & \multicolumn{3}{|c|}{ Total shrinkage / Ukupno utezanje } & \multirow{2}{*}{$\begin{array}{c}\begin{array}{c}\text { Fiber saturation } \\
\text { point }\end{array} \\
\text { Točka zasićenosti } \\
\text { vlakanaca FSP }\end{array}$} \\
\hline & & $\begin{array}{c}\text { radial } \\
\text { radijalno } \\
\beta \mathrm{r} \\
\end{array}$ & $\begin{array}{c}\text { tangential } \\
\text { tangencijalno } \\
\beta \mathrm{t} \\
\end{array}$ & \begin{tabular}{|c|} 
volumetric \\
volumno \\
$\beta \mathrm{v}$ \\
\end{tabular} & \\
\hline & $\mathrm{kg} \cdot \mathrm{m}^{-3}$ & \multicolumn{3}{|c|}{$\%$} & $\%$ \\
\hline African mahogany / afrički mahagonij & 560 & 3.7 & 5.6 & 11.0 & 28.3 \\
\hline African padouk / afrički padouk & 590 & 3.3 & 5.3 & 7.8 & 17.7 \\
\hline Courbaril / jatoba & 910 & 4.4 & 8.6 & 12.0 & 20.4 \\
\hline Cumaru / kumaru & 1125 & 5.6 & 7.9 & 16.1 & 22.1 \\
\hline Doussié / afzelija & 720 & 3.1 & 4.6 & 8.7 & 19.7 \\
\hline European beech / bukva & 670 & 6.0 & 14.1 & 16.7 & 31.2 \\
\hline European oak / hrast & 647 & 4.5 & 9.7 & 13.6 & 28.0 \\
\hline Ipe / ipe & 900 & 5.3 & 6.7 & 12.7 & 18.7 \\
\hline Iroko / iroko & 530 & 3.5 & 5.6 & 10.2 & 23.2 \\
\hline $\begin{array}{l}\text { Light red meranti } \\
\text { svjetlocrveni meranti }\end{array}$ & 450 & 3.9 & 8.9 & 13.5 & 28.2 \\
\hline Massaranduba / balata & 1070 & 7.1 & 9.5 & 21.0 & 28.0 \\
\hline Merbau / merbau & 825 & 4.1 & 6.1 & 11.5 & 29.6 \\
\hline Opepe / opepe & 680 & 4.5 & 8.1 & 12.7 & 23.1 \\
\hline Owangkol / bubinga & 945 & 4.1 & 8.2 & 13.8 & 24.2 \\
\hline Sapele / sapele & 640 & 5.1 & 7.3 & 13.5 & 28.7 \\
\hline Scots pine / obični bor & 470 & 5.1 & 7.3 & 13.5 & 30.0 \\
\hline Sucupira / brazilski lješnjak & 945 & 4.9 & 7.1 & 14.4 & 23.6 \\
\hline Tatajuba / tatajuba & 890 & 3.8 & 5.5 & 10.9 & 20.5 \\
\hline Tauari / brazilski hrast & 840 & 4.5 & 7.2 & 14.4 & 28.7 \\
\hline Teak / tik & 650 & 2.5 & 5.7 & 7.8 & 22.5 \\
\hline Wenge / wenge & 820 & 5.9 & 9.1 & 14.6 & 21.1 \\
\hline
\end{tabular}


that only $24 \%$ of the variation in volumetric shrinkage was accounted for by wood basic density. However, when European wood species were not included in this analysis, the relationship between the basic density and volumetric shrinkage of wood was statistically significant $\left(R^{2}=0.44\right)$. According to Babiak and Kúdela (1995), the wood density and its structure play important roles. The species tested here revealed a similar structure of diffuse-porous wood. In some (Courbaril, Light red meranti) but not all cases, an expanded axial parenchyma was observed.

\section{CONCLUSIONS}

\section{ZAKLJUČAK}

In this study, sorptive properties of wood species used in floors production in Europe were determined and compared. In the course of research, 17 tropical wood species were tested and analyzed. For comparison, selected European wood species - European beech, European oak and Scots pine, were also tested.

Findings and results show that equilibrium moisture content of tropical wood species is lower than that of temperate zone wood species. African padouk, Teak, Afzelia and Ipe showed the lowest values of moisture content. Furthermore, these wood species showed the lowest values of fiber saturation point (17.7\% for African padouk, $22.5 \%$ for Teak, $19.7 \%$ for Doussié and $18.7 \%$ for Ipe). Among tropical wood species, Light red meranti and Massaranduba samples showed the highest values of moisture content at different air conditions. Furthermore, it was established that wood density affected positively volumetric swelling of tested tropical hardwoods. Regression analysis indicated a statistically significant relationship when the coefficient of volumetric total shrinkage was considered. Thus, the higher wood density, the higher are the dimensions changes.

The results provide crucial knowledge applicable in practice in using many tropical wood species. Furthermore, this indicates that a common recommendation should be considered for all wood species. Based on the results obtained, the possibility of supplementing the recommendations in industry standards regarding wooden floors and other applications of wood should be considered, especially in case of recommended values of moisture content. It would help to avoid significant problems during production, installation and exploitation of wooden products such as floors.

\section{REFERENCES}

\section{LITERATURA}

1. Adamopoulos, S.; Voulgaridis, E., 2012: Effect of hotwater extractives on water sorption and dimensional changes of black locust. Wood Research, 57 (1): 69-78. https://doi.org/10.1007/s00107-002-0329-6.

2. Babiak, M.; Kúdela, J., 1995: A contribution to the definition of the fiber saturation point. Wood Science and Technology, 29 (3): 217-226.

https://doi.org/10.1007/BF00204589.
3. Choong, E. T.; Achmadi, S. S., 1991: Effect of extractives on moisture sorption and shrinkage in tropical woods. Wood and Fiber Science, 23 (2): 185-196.

4. Deliiski, N., 2011: Evaluation of wood sorption models and creation of precision diagrams for the equilibrium moisture content. Drvna industrija, 62 (4): 301-309. https://doi.org/doi:10.5552/drind.2011.1115.

5. Hernández, R. E., 2006: Effects of extraneous substances, wood density and interlocked grain on fiber saturation point of hardwoods. Wood Material Science and Engineering, 2 (1): 45-53. https://doi.org/10.1080/17480270701538425.

6. Hernández, R. E., 2007: Swelling properties of hardwoods as affected by their extraneous substances, wood density, and interlocked grain. Wood and Fiber Science, 39 (1): 146-158.

7. Jannot, Y.; Kanmogne, A.; Talla, A.; Monkam, L., 2006: Experimental determination and modelling of water desorption isotherms of tropical woods: afzelia, ebony, iroko, moabi and obeche. Holz als Roh- und Werkstoff, 64 (2): 121-124. https://doi.org/10.1007/s00107-005-0051-2.

8. Jankowska, A.; Kozakiewicz, P., 2016: Determination of fibre saturation point of selected tropical wood species using different methods. Drewno, 59 (197): 89-97. https://doi.org/10.12841/wood.1644-3985.C07.12.

9. Jankowska, A.; Drożdżek, M.; Sarnowski, P.; Horodeński, J., 2017: Effect of Extractives on the Equilibrium Moisture Content and Shrinkage of Selected Tropical Wood Species. BioResources, 12 (1): 597-607. https://doi.org/10.15376/biores.12.1.597-607.

10. Keylwerth, R., 1969: Praktische Untersuchungen zum Holzfeuchtigkeits-Gleichgewicht. Holz als Roh- und Werkstoff, 27 (8): 285-290. https://doi.org/10.1007/BF02612702.

11. Krzysik, F.; Sobczak, K., 1960: Wilgotność drewna w pomieszczeniach ogrzewanych centralnie (Wood moisture content in centrally heated rooms). Sylwan 9: 29-43.

12. Mantanis, G. I.; Young, R. A.; Rowell, R. M., 1994: Swelling of wood. Part I: Swelling in water. Wood Science and Technology, 28 (2): 119-134.

https://doi.org/10.1007/BF00192691.

13. Popper, R.; Niemz, P.; Croptier, S., 2009: Adsorption and desorption measurements on selected exotic wood Species. Analysis with the Hailwood-Horrobin model to describe the sorption hysteresis. Wood Research, 54 (4): 43-56. https://doi.org/10.3929/ethz-a-006104740.

14. Popper, R.; Niemz, P.; Eberle, G., 2007: Influence of extractives on water vapour sorption by the example of wood species from Chile. Wood Research, 52 (1): 57-68. https://doi.org/10.3929/ethz-a-006115795.

15. Popper, R.; Niemz, P.; Torres, M., 2006: Einfluss der Extraktstoffe ausgewählter fremdländischer Holzarten auf die Gleichgewichtsfeuchte. Holz als Roh- und Werkstoff, 64: 491-496.

https://doi.org/10.1007/s00107-006-0132-x.

16. Salin, J. G., 2011: Inclusion of the sorption hysteresis phenomenon in future drying models. Some basic considerations. Maderas. Ciencia y tecnología, 13 (2): 173-182. https://doi.org/10.4067/S0718-221X2011000200005.

17. Simo-Tagne, M.; Rémond, R.; Rogaume, Y.; Zoulalian, A.; Bonoma, B., 2016: Sorption behavior of four tropical woods using a dynamic vapor sorption standard analysis system. Maderas. Ciencia y tecnología, 18 (3): 403-412. https://doi.org/10.4067/S0718-221X2016005000036.

18. Wangaard, F. F.; Granados, L. A., 1967: The effect of extractives on water-vapour sorption by wood. Wood Science and Technology, 1 (4): 253-277. https://doi.org/10.1007/BF00349758. 
19. Wanschura, R.; Windeisen, E.; Richter, K., 2014: Analysis of extractives of tropical hardwoods and benefits for the surface treatment. IAWS Plenary Meeting 2014 - Eco-Efficient Resource Wood With Special Focus On Hardwoods, Sopron \& Vienna, 15-18 ${ }^{\text {th }}$ September 2014: 71-72.

20. Wróżek, B.; Romanovski, V., 2014: Podłoga drewniana bez szpar (Wooden floor without cracks). Profesjonalny parkiet, 2 (76): 46-48.

21. ***ISO 3130 (1975) Wood. Determination of moisture content for physical and mechanical tests.

22. ***ISO 3131 (1975) Wood. Determination of density for physical and mechanical tests.

23. ***ISO 4858 (1982) Wood. Determination of volumetric shrinkage.

24. ***PN-D-04100 (1977) Drewno. Oznaczanie wilgotności. (Wood. Determination of moisture content.)

25. ***PN-D-04101(1977) Drewno. Oznaczanie gęstości. (Wood. Determination of density.)

26. ***PN-D-04111 (1982) Drewno. Oznaczanie skurczu i spęcznienia. (Wood. Determination of shrinkage and swelling.)

27. ***PN-EN 13226 (2009) Podłogi drewniane. Elementy posadzkowe lite z wpustami i/lub wypustami. (Wood flooring. Solid parquet elements with grooves and/or tongues.)
28. ***PN-EN 13227 (2004) Podłogi drewniane. Lamparkiet $\mathrm{z}$ drewna litego. (Wood flooring. Solid lamparquet products.)

29. ***PN-EN 13556 (2005) Drewno okrągłe i tarcica. Terminologia stosowana $\mathrm{w}$ handlu drewnem w Europie. (Round and sawn timber. Nomenclature of timbers used in Europe.)

30. ***PN-EN 13629 (2012) Podłogi drewniane. Deski pojedyncze lite oraz deski łączone $\mathrm{z}$ litych elementów $\mathrm{z}$ drewna liściastego. (Wood flooring. Solid individual and pre-assembled hardwood boards.)

\section{Corresponding address:}

\section{AGNIESZKA JANKOWSKA, Ph.D.}

Department of Wood Sciences and Wood Protection Faculty of Wood Technology

Warsaw University of Life Sciences - SGGW

Nowoursynowska 159 St.

02-776 Warsaw, POLAND

e-mail: agnieszka_jankowska@sggw.pl 